This is the final peer-reviewed manuscript that has been published as

Hammer, N. (2010) Cross-border Cooperation under Asymmetry - The Case of an Interregional Trade Union Council, European Journal of Industrial Relations 16 (4), 351-367. doi: 10.1177/0959680110384535

\title{
Cross-border cooperation under asymmetry: The case of an interregional trade union council
}

\author{
Nikolaus Hammer \\ University of Leicester, UK \\ Corresponding author: \\ Nikolaus Hammer, University of Leicester, Centre for Labour Market Studies, 7-9 Salisbury Road, Leicester LE1 \\ 7QR, UK \\ e-mail: nikolaus.hammer@le.ac.uk
}

\begin{abstract}
In order to protect minimum wage and social standards in cross-border regions marked by considerable economic disparities, trade unions have built cooperation structures across adjoining (usually sub-national) regions. Since the 1970s more than 40 Interregional Trade Union Councils (IRTUCs) have been established. This article investigates emerging practices of cross-border trade union cooperation in the West Pannonia region between Eastern Austria and Western Hungary. It argues that IRTUCs can play an important role in fuelling cooperation to preserve wages and labour rights in cross-border regions, particularly in sectors with high precarious employment. While actual practices are contingent on regional union strategies as well as industrial relations and labour market institutions, cross-border cooperation occupies an important place within European industrial relations practices and can support new forms of capacity-building.
\end{abstract}

\section{Keywords}

cross-border region, trade union cooperation, Interregional Trade Union Council, European industrial relations, Austria, Hungary

\section{Introduction}

Political and academic debates on developing cross-border trade union and bargaining coordination, as well as the industrial relations processes at European level, have focused on European Works Councils 
(EWCs) and (sectoral) social dialogue (Lecher et al., 2001; Marginson and Sisson, 2004). When it comes to unilateral trade union cooperation, the main emphasis is on bargaining coordination at sectoral level (Gollbach and Schulten, 2000; Traxler et al., 2008). However, parallel to these processes, we can observe the emergence of a large number of Interregional Trade Union Councils (IRTUCs) over the last three decades. These councils were established as bottom-up initiatives in order to deal with labour market problems in adjoining (usually sub-national) regions in different EU countries (in a few cases including non-EU states). The analysis in this article is concerned with the functions and forms of cross-border cooperation in IRTUCs which, it is argued, is shaped by a number of asymmetries in the industrial relations and labour market institutions across their constituent regions. For example, their remit has to be limited to interregional labour markets as cross-border regions do not overlap sufficiently with product markets. Equally, it has to be limited to trade union cooperation, rather than bargaining coordination, as the regional level rarely has a role in bargaining processes. Thus, the focus of IRTUCs has to be protecting minimum wages and social standards in the face of disparities across borders in the first instance. However, the increasing role of the regional level and EU regional policy, as well as the importance of linking the local and the global in crossborder trade union networks, could give more weight to interregional trade union action.

The emergence of IRTUCs prompts important questions as to the function, substance and form of interregional trade union cooperation in the face of economic disparities; across different industrial relations systems, trade union interests and strategies; about the leverage cooperation can exert on interregional labour market dynamics and solidarities. The argument put forward here is that IRTUCs constitute a strategic and organizational answer in order to protect minimum wages and social standards. While this is where the interests of the unions within the IRTUCs meet, the actual forms of cross-border cooperation are the result of inter-union compromises on social dialogue(s), institutional and informal trade union networks, as well as capacity-building and organizing, a combination which depends on each institutional and strategic context. Cooperation within IRTUCs is important, as it captures economic and social issues at a geographical scale that escapes cross-border social dialogue and bargaining coordination. This article first discusses IRTUC cross-border cooperation in general and a case study of the IRTUC West Pannonia, situated at the border between Austria and Hungary. This provides the background for an analysis of functions of and forms of IRTUCs, and how these relate to wider issues of cross-border trade union cooperation.

\section{What function for interregional trade union cooperation?}

Recent debates on cross-border bargaining coordination in Europe have stressed the structural asymmetry that stems from the economic constraints of the Single European Market and European Monetary Union on the one hand, and the nationally based industrial relations systems of the member 
states on the other. The opening of capital markets as well as the abandonment of inflation and exchange rate policies to support employment goals has increased pressures to use wage policies for economic adjustment. The 2004 enlargement round has further increased the challenges of crossborder bargaining cooperation, since single-employer bargaining systems and relatively weak and fragmented trade unions dominate the industrial relations systems in the New Member States (NMS) (Slovenia is the notable exception).

So far, the broad focus of unions' strategic efforts as well as academic debates has been on the sectoral level. Given the development of the European sectoral social dialogue, of initiatives to coordinate inter-national bargaining and political pressure from the European Commission (including specific regulation in some sectors), the sectoral level constitutes the actual (if weak) terrain of bargaining coordination (Marginson, 2005; Marginson and Traxler, 2005; Schulten, 2003). The theoretical rationale for the importance of the sectoral level refers back to Commons (1909) and holds that trade union coordination needs to be aligned to the scope of market integration in order to counter the asymmetries in the regulation of capital on the one hand, and of employment and social issues on the other (Marginson and Traxler, 2005: 424). Here, a related issue concerns the actual process through which coordination is to be achieved, an issue that is further complicated at European level by the dominance of single-employer bargaining in most NMSs. First, reflecting the weakness of trade union organization both at sectoral level and in the workplace, bargaining coverage is relatively low in most NMSs, ranging from under 20 percent in Lithuania and Latvia to 100 percent in Slovenia (Visser, 2004: 30). Second, such structures result in obvious difficulties in establishing and aligning vertical and horizontal coordination. Third, there is the tricky issue of establishing cross-border bargaining coordination between single and multi-employer systems. Marginson and Traxler (2005) argue that a strong trade union presence in lead firms could help in establishing a 'going rate' and thereby provide a substitute for sectoral collective bargaining, leading to a differentiated (according to the circumstances of the sector) and dual strategy (linking multi-employer with single-employer bargaining). Traxler et al. (2008) have recently underlined the logical potential of pattern bargaining as well as its likely empirical use as a latent form of coordination.

In contrast to such inter-national bargaining coordination at sectoral level, IRTUCs represent a bottom-up form of cooperation on securing economic and social minimum standards in cross-border labour markets. Their development --- their increasing institutionalization as well as differentiation of strategies --- reflects their particular embeddedness in inter-regional political economies which result in very different challenges for cross-border trade union cooperation in the various IRTUCs. The first IRTUCs were founded in the late 1970s in the core EU industrial regions and were furthered by three developments. First, industrial decline in mining and steel and the threat of competitive adjustment at the expense of the workers led unions to cooperate; the first IRTUC was formally established in 1976 by the DGB Saarland representatives, the regional structures of the CGT-FO in Lorraine (later joined by CFDT) and the Luxembourg OGB-L (Müller, 1994: 258). Second, the integration of labour 
markets in those regions and the increase of cross-border workers provided an important terrain as IRTUCs advised on and campaigned for the removal of disadvantages that resulted from differences in tax and social insurance legislation. Different bases for the calculation of benefits, for example, often disadvantaged cross-border workers and sometimes led to double taxation without corresponding benefits on either side of the border. Particularly in regions with a long tradition of cross-border working --- along the borders of France, Belgium, Germany, Switzerland --- self-help associations often preceded and competed with IRTUCs, certainly with regard to advice as well as political lobbying for bilateral treaties on taxation and social insurance (Hamann, 2005). Third, IRTUCs have developed parallel to European structural and cohesion policies as well as the cross-border cooperation of local and/or regional authorities within so-called Euroregions at internal and external borders of the EU (see Perkmann, 2007). While not a formal actor in Euroregions, IRTUCs have filled a void in labour's presence in the multi-level European polity and have become a vehicle to campaign on economic, labour market and social policy issues. Thus economic restructuring, liberalization and European integration posed incentives for cross-border union cooperation, in the face of increasing cross-border disparities of economic growth, employment and wages in successive waves of enlargement.

Against this background, IRTUC cooperation raises an obvious question: if inter-national bargaining coordination has been difficult to establish at sectoral level, why should cooperation at the inter-regional level --- with incongruent product and labour markets, and trade unions without a role in bargaining --- have better chances of success? Any answer will have to take into account the particular institutional and strategic set-up in a cross-border region; however, we can still highlight three key parameters. First, wage disparities and, consequently, labour market pressures only become a problem where differences in industrial relations and welfare systems can be exploited. This tends to be more pronounced in cross-border regions, particularly in the most recent generation of IRTUCs with NMS regions, and thereby poses incentives for coordination. Labour market pressures exist even where full labour mobility has been restricted for the time being, as this encourages mobility in the form of selfemployed, illegal and informal labour (Donaghey and Teague, 2006) and has repercussions on the low-wage segments, social security systems and labour standards for workers in the host and home countries. Second, while unions might have similar interests in interregional convergence in the longterm (stemming an exodus of workers from the low-wage region, safeguarding minimum conditions in the high-wage region), their short-term interests (e.g. regarding the speed or routes towards convergence) might well be different. Third, given the structural place of IRTUCs in their respective industrial relations systems, the economic and social functions of cross-border cooperation have to be sought outside collective bargaining (Traxler and Mermet, 2003 discuss this with regard to wage coordination). Thus, against the background of disparate levels of economic development, their economic function is to monitor the integration of interregional labour markets and protect wage and employment levels without giving in to pressures of competitive regionalism (Dörre and Röttger, 
2005); their social function is to safeguard labour standards, terms of employment, minimum wages and benefits from downward pressures. Importantly, it is mainly the latter area where unions have strategic and organizational capacities to build meaningful cooperation.

While the goals and interest constellations of cross-border cooperation are different from bargaining coordination, the social networks they are based on are not too dissimilar. Schulten (2003: 118), for example, reports on the cooperation of $I G$ Metall districts with cross-border partner unions:

Although these networks still vary a good deal in terms of their form, scope and the intensity of cooperation, issues dealt with so far include:

- mutual exchange of trade union observers during collective bargaining rounds including mutual participation in trade union bargaining committees; negotiation with the employers and industrial action,

- the development of a common day-to-day information system on collective bargaining issues,

- common training seminars on the system of collective bargaining and trade unions' collective bargaining policy,

- common working groups on different collective bargaining issues,

- mutual recognition of trade union membership

This underlines the importance of establishing social networks and organizational capacity in overcoming collective action problems and developing cooperation on, both, economic as well as social issues. IRTUCs' cross-border cooperation focuses on building trust and solidarity via information on employment regulations, legal advice and support (thereby drawing workers into unions instead of self-help associations; Hamann, 2005); representation of cross-border commuters and migrants within as well as outside the labour movement; the function of a resource to facilitate and support cross-border networks at sectoral and company level as well as trade union capacity (training on organizing and bargaining skills); and political representation vis-à-vis regional authorities (see below; Müller, 1994). In this respect, IRTUCs can play an important role at the border of the NMSs and articulate a number of factors that are considered central for trade union revival (Ost, 2009). Their forms and terrains of cooperation span the entire 'geometry of trade unionism' (Hyman, 2001) while the actual form of cross-border networks and practices of cooperation are the result of a strategic compromise by the unions involved, based on the opportunities afforded by the respective institutional frameworks.

The following section presents a case study of the IRTUC West Pannonia in the cross-border region of Eastern Austria and Western Hungary. Fieldwork was conducted between August 2006 and March 2007 and included interviews with regional trade union officers at the peak and sectoral organizations (10), IRTUC staff (3), a panel with workplace representatives in Szombathely 
(Hungary), attendance at a transport worker Stammtisch (see below) in Gols (Austria), a border picketing event at Andau/Jánossomorja, as well as the presentation of a survey of cross-border workers (ÖGB/IGR, 2007). The research also included analysis of IRTUC documentation as well as interim reports for the European Commission (Gutknecht-Gmeiner and Henkel, 2005).

\section{The IRTUC West Pannonia}

Cross-border contacts between trade unionists in Burgenland, in the far east of Austria, and Western Hungary stretch back to the 1980s. In the mid-1990s personal networks were intensified and transformed into substantive cooperation, for example through workshops on the social, labour market and industrial relations systems in each country, and training for Hungarian unionists on specific issues such as re-employment schemes and collective bargaining. As this interregional trade union cooperation evolved, the mid-1990s saw a further set of developments that spurred the formation of an IRTUC: the quota for foreign workers in the Austrian labour market was continuously increased; in 1995 Austria became a member of the EU; collaboration between Austrian and Hungarian regional authorities resulted in the foundation of the Euregio West/Nyugat Pannonia in 1998; and Hungarian EU accession became a serious prospect. These were major incentives to institutionalize cross-border trade union cooperation; the IRTUC was agreed in October 1998 and formally launched in July 1999.

The IRTUC was established by the Burgenland regional organization of the Austrian trade union confederation ÖGB, and the regional organizations of MSzOSz, the largest Hungarian confederation, in the counties of Györ-Moson-Sopron, Vas and Zala. The formal structure comprises a conference, an executive committee, working groups and a control commission in which all regions are represented. The chair of the IRTUC rotates between regions in parallel with the rotating presidency of the Euregio West/Nyugat Pannonia. The founding document outlined very ambitious programmatic goals, given the resource constraints of the executive and the member unions (IGR Burgenland/Westungarn, 1999). They ranged from trade union cooperation at sectoral and company level on social and labour market policies, to the harmonization of social minimum standards, working conditions and collective bargaining agreements. In the words of an ÖGB official:

The impulse was to reflect on how the union can shape integration when very different wage levels meet, when we will see large numbers of cross-border commuters... without this resulting in too adverse labour market impacts, so that Austrians accept Hungarian cross-border workers, to prevent the emergence of xenophobic tendencies, in other words, measures that have an impact in terms of democracy, union policy, workers' rights, labour market policy.... If you look at our initiatives in the region, starting with information events or workplace-level activity, with Hungarian workers, the main objective is for them to have maximum information and a 
strong representation in order to make it virtually impossible for employers to play off foreign against domestic workers.

Given the large gap between ambitions and resources, the IRTUC sought outside funding for its labour market initiatives. This resulted in a number of projects under the EU initiative INTERREG IIIA/Phare CBC, launched to facilitate cross-border cooperation involving the NMSs. The IRTUC project for the Austrian part received more than $€ 1.8$ million between July 2002 and December 2007, while the Hungarian side's funding came from two smaller Phare CBC projects (each under $€$ $100,000)$ that were conceptually linked to the INTERREG project. It is important to distinguish between the IRTUC as a political institution and as a labour market project: apart from political and functional differences, the former was concluded between the regional organizations of ÖGB and MSzOSz alone, while the latter also included the smaller Hungarian unions MOSz, SzEF, Autonomok, ESzT and Liga. Still, the range of initiatives discussed below were mainly based on the well staffed project office in Eisenstadt (Austria), with 5 bilingual full-time employees, partly with postgraduate legal education, and MSzOSz regional offices in Györ-Moson-Sopron, Vas and Zala. In order to situate the main IRTUC initiatives the following section gives a brief overview of the interregional labour market.

\section{Different labour market and industrial relations systems}

Economic growth and average wages have converged in Burgenland and Western Hungary over the last 15 years, although structural change and increased labour market integration had a more differentiated impact at sectoral level (with persistent north-south disparities). While Burgenland's GDP grew from 62.9 percent of the Austrian average in 1995 to 69.8 percent in 2004, Western Hungary maintained its above-average position compared to the rest of the country (103 percent to 104.4 percent; data in this paragraph are from Eurostat). Employment in Burgenland grew by 5.7 percent between 1995 and 2004, well above the Austrian average of 1.1 percent; a decline in manufacturing employment was more than offset by increases in wholesale and retail, hotels and tourism and transport. Western Hungary, however, recorded a 0.7 percent decline in employment over the same period, which contrasted with the 1.9 percent increase in Hungary as a whole; here, it was the construction industry, hotels and tourism and manufacturing that experienced strong employment growth. Unemployment in the two regions is roughly comparable, averaging 4.5 percent and 4.7 percent respectively between 1999 and 2006. This is slightly above the Austrian average but a considerable 1.8 percent below the average for Hungary. During the period 1996-2007, hourly labour cost differentials in manufacturing between Hungary and Austria remained significant at an essentially constant 1:3 ratio in purchasing power parities. 
In these economic conditions, the influx of (mainly) Hungarian cross-border workers had an impact on the structure of the labour market. Overall employment in Burgenland increased by 32.7 percent to 88,000 between 1989 and 2007, while foreign employment rose more than eightfold and that of Hungarian citizens more than 13 times, although from a low level of 474 to 6,561 (data in this paragraph are from Arbeitsmarktservice Österreich, the Austrian public employment service). At the same time, about a third of Burgenland's workers commute further west to work, mainly in the Vienna region. Hungarians accounted for 68 percent of foreign workers in 2007, up from 37 percent in 1989, thereby replacing the 'traditional' guest workers of the 1960s and 1970s from Turkey and former Yugoslavia. This influx has happened despite significant barriers to workers' freedom of movement (the Austrian social partners agreed to open the labour market only after the full transitional period has ended in 2011). At present, foreigners can work in Austria only under a complex set of quotas and different (fixed-term) employment statutes which are being monitored by the authorities and social partners. Thus, a considerable proportion of the 6,561 Hungarian workers comprise daily cross-border commuters (Grenzgänger), seasonal workers and harvest assistants (in 2007 the contingents for Burgenland were 2,350, 625, 1,800 respectively). In 2007 a further category for skilled workers was introduced with a quota of 800 for turners, welders and milling operators; both the quota as well as the permissible jobs were expanded considerably for 2008.

This context engenders a highly segmented labour market. While skilled Hungarian workers can work as self-employed across the border, Hungarians with low skills work under the selective quota of renewable work permits. For example, Hungarians make up 45 and 27 percent of employment in agriculture and hotels and tourism; other major sectors with above-average representation are construction and transport (ÖGB/IGR, 2007: 5). Three-quarters are male, while 82 percent have left their jobs in Hungary to take up employment in Burgenland (ÖGB/IGR, 2007: 11). They tend to be better qualified than their Austrian counterparts, while earning around 20 percent less; only one-third is sure that pay and benefits are according to their entitlements. Another important dividing line is between the formal and informal segments: about a quarter say their employment is unregistered or incorrectly registered (particularly in hotels and tourism and in agriculture), and it can be assumed that the real figures are higher (ÖGB/IGR, 2007: 25).

Institutions, resources and capacities to control the labour market are vastly different on the two sides of the border. Austria has comprehensive industry-wide bargaining and almost 100 percent coverage (Traxler et al., 2008), based on extension provisions, encompassing employer organization and good union density (although the latter declined in Burgenland from 63 percent in 1995 to 50 percent in 2005). Hungarian collective labour is fragmented and weak, with union density in Western Hungary around 20 percent. There is a decentralized system of wage determination which privileges the company or workplace level (Neumann, 2002), while sectoral bargaining is ineffective; an interviewee put bargaining coverage at 35 percent (MSzOSz officer, Zala). Resources shed another clear light on capacity: while the ÖGB Burgenland employs about 10 officers (in addition to those 
working for the affiliated industrial unions and directly for the IRTUC), for a working population of 86,600 (2004), confederations in Western Hungary have difficulty in establishing county-level structures for the 374,000 employees; in 2002, for example, MSzOSz reduced representation to one full-time officer per region (thereby anticipating the restructuring of regional authorities) (interview, MSzOSz officer, Vas). An important institution of labour market information and control, however weak, is that of regional tripartite partnership on both sides of the border. In Austria, unions work closely with the regional Arbeitsmarktservice and authorities on quotas and labour market policy; similarly in Hungary, the tripartite County Labour Councils provide an important entry point for unions into regional labour market policy, although inter-union competition does not allow for the development of a stable corporatist project (Horesnyi and Tóth, 2006).

The significant differences in labour market institutions, dynamics and union capacities pose major questions for interregional labour market control, and thus for the objects and mechanisms of interregional trade union cooperation. In the following sections, IRTUC activities regarding information and advice, company and sector-level cooperation as well as its social partner functions will be discussed.

\section{Information and advice beyond servicing}

The starting point for IRTUC work to contain the adverse effects of the interregional labour market was to act as a broker of information and point of advice for cross-border workers and trade unionists at sectoral and company levels. This provided a stepping stone to building horizontal cross-border networks at these levels and to develop IRTUC activities outside as well as within the workplace. Broadly we can distinguish between four different types of activities.

First, informing Hungarian as well as Austrian workers about their entitlements in wages, supplements, benefits and working conditions as defined in collective agreements is seen as a basis for fighting wage dumping. In this process, the IRTUC has developed numerous bilingual brochures on employment rights, tax and benefit matters, guides on the establishment and rights of works councils and collective bargaining, a dictionary on work and employment terminology, as well as a handbook for transport workers on the regulations that apply in their sector (Grundtner and Eberl, 2006). It has picketed border crossings, reaching 800-1,000 cross-border workers. Furthermore, the IRTUC, with the support of its sectoral unions, has organized social events for workers where topical work and employment issues are discussed, drawing between 60-350 people per event; and has also supported Stammtisch events, which take place more regularly, particularly in the transport, agriculture and service sectors. Traditionally, a Stammtisch is a regular location in a pub which functions as a stage to play cards or deliberate local gossip and politics; but in this case the Stammtisch framework is used innovatively as a platform outside the workplace for information on work and employment issues in a 
trade union context. It is not coincidental that sectors dominated by small and medium-sized enterprises are at the forefront here. A Burgenland official from vida, the transport and services union, said in an interview:

After the vocational training for lorry drivers, there was nothing... so we tried to get them together regularly to brush up on new regulations. I have seen this Stammtisch format [elsewhere] and I did not want to make the same mistake: talk about the union, the union, the union; people jut get fed up with it. So we packed a lot of information into this and got speakers from the Ministry of Finance when they wanted to know about tax issues, the labour inspector, inspectors of foreign employment, people from the health and pension insurance. And when a lot of the labour market shifted abroad, then we obviously invited the Hungarians.

Initially, according to an IRTUC/ÖGB officer,

Austrians and Hungarians looked at each other disparagingly, along the lines of 'this is who is responsible for wage dumping in my sector, idiot, we'll show him'. The interesting thing was that the Hungarians asked questions and explained the pressures they are under, and then the Austrians realised it is not they who are responsible for wage dumping; that it is someone completely different and then the real power relations become apparent. In the end there was fraternization, they got the interpreters out of their boxes and then the lorry drivers started talking amongst themselves.

Second, the creation of decentralized structures of support and advice played an important part in building the profile of the IRTUC. This was organized in conjunction with ÖGB legal secretaries at federal and sectoral level, as well as the Arbeiterkammer (Chamber of Labour). Bilingual legal advice is offered regularly in five different locations across Burgenland, in the ÖGB district offices, and has assisted an increasing number of employees: 7,000 from March 2004 to September 2006; 3,800 alone in 2006. In 2004 ÖGB and MSzOSz concluded a membership recognition agreement so that the ÖGB now represents Hungarian cross-border workers in the labour courts.

As this advice and support are intended to prevent or redress the violation of cross-border workers' terms and conditions of employment, the IRTUC, thirdly, has in this process been able to monitor the labour market and to develop vast expertise on social insurance, labour and tax law as well as the various statutes and quotas under which foreign workers can be employed. The understanding gained here allowed it to identify and target specific problem sectors (advice was predominantly sought from employees in agriculture, transport, food production, pubs and restaurants) or specific groups (seasonal harvesters, women, young and old workers), issues that were taken up again in the Stammtisch events (interview, IRTUC/ÖGB official). 
Fourth, the IRTUC has increasingly developed a publicity, awareness-raising and lobbying function, both externally as well as within the labour movement. Information events and exposure of severe employment rights violations have served to lobby public authorities and establish a good presence in the local media. This array of initiatives could only be developed and sustained with the active involvement of sectoral unions and works councils (see below), thus offering avenues for crossborder cooperation for the latter and raising their awareness for the specific problems of the opening interregional labour market. Particularly where union organization is fragmented and weak, the IRTUC information events offer an important structure and function outside the workplace that unions are not able to fulfil, such as in Western Hungarian agriculture (interview, MSzOSz officer, GyörMoson-Sopron).

Thus, while the emphasis of these initiatives was on individual cross-border workers, they broadened established trade union practices and concerns, with the use of innovative formats such as the Stammtisch. This made it possible to bring work, employment and trade union issues into social spaces outside the workplace, to target workers in the informal sector and to frame issues in terms of work, employment and trade union rights, rather than as specific and separate concerns for Hungarian cross-border workers.

\section{Trade union cooperation at sectoral and company levels}

Trade union cooperation at sectoral and company level has developed considerably and more systematically through the involvement and the resources of the IRTUC. While the basis was laid through joint training for union officers and works councillors, the IRTUC aimed to develop structures of interest representation and build sustainable cross-border networks at sectoral level as well as between works councillors. Facilitating horizontal cross-border consultation and cooperation (as opposed to recourse through the formal channels of the national and regional unions) is central to the work of the IRTUC, and has resulted in weekly contact, for example, between the railway unions as well as in some other sectors and companies. However, cross-border cooperation at company level is hampered by the fragmentation and weak union presence in Hungarian workplaces. In this situation, the Hungarian unions have used the IRTUC to bolster their legitimacy at sectoral level, trying to substitute for the gap at company level.

Cooperation at sectoral level is mostly on the process of preparing bargaining claims and conducting negotiations, particularly in the metals, textiles and leather, commerce and transport, hotels and tourism and railway sectors. It is the training in collective bargaining that is central here rather than actual bargaining cooperation; for example, Hungarian unionists have been observers in the collective bargaining negotiations with the social insurance board and the retail sector in Vienna. In 
the other direction, Austrian unionists took part in the tripartite working commission for a sectoral agreement in construction and woodworking in Hungary (interview, IRTUC/ÖGB official).

In some sectors such as railways, because of the concentrated ownership structure (in other words, the dominance of the former state-controlled railways) and well developed trade unions, interregional meetings between unionists and works councillors have been established, meeting almost monthly (interview, vida official). The conditions for this kind of cooperation (in contrast to the Stammtisch) lie in the structure of the sector and the degree and capacity of union organization. In the case of the railway unions, cooperation has become institutionalized and regularized independently of the leadership of the IRTUC, and the networks and trust developed here have already been tested in strike action. In 2003, for example, the ÖGB organized a strike against cutbacks in the pension system and noticed that management of the Austrian railways was preparing to use Hungarian train drivers to break the strike. However, good networks between the unions and the Hungarian train drivers' solidarity ensured that all trains were stopped (Interview, ÖGB Burgenland official).

At company level the aim was to build networks between works councillors in Austrian SMEs and their counterparts in Hungarian subsidiaries. A 2004 study by the IRTUC found around 380 Austrian employers in Györ-Moson-Sopron, 320 in Vas and 350 in Zala, whereas there were only 20 Hungarian enterprises or entrepreneurs in Burgenland (interview, MSzOSz official, Zala). The focus was twofold: on Austrian companies in Burgenland with a high proportion of Hungarian workers on the one hand, and on foreign (mainly Austrian) SME subsidiaries in Hungary on the other. In the first case, the IRTUC has supported workplace representation of Hungarian workers; in the second, it is facilitating company-level cross-border networks. Coordination of bargaining at company level offers another important point of leverage where (mainly Austrian) companies have subsidiaries in Hungary. For example, at Delphi Packard, an automotive supplier with factories within $20 \mathrm{~km}$ on either side of the border, as well as Falco, a chipboard producer, efforts have been made to coordinate claims and provisions on 'various social issues, non-wage benefits, procedures and benefits for laying off staff' (interviews, MSzOSz official, Vas and ÖGB Burgenland official). For union representatives in these companies, the technical and comparative information was considered very important, as were the cross-border networks as such:

We have basic [cross-border] contact, cooperation is less continuous than issue-based, for example about redundancies, wages, the relocation of production; when we have problems then we get in touch with each other... The very fact that management knows that I attend IRTUC meetings and now and then meet my opposite number in [Burgenland], this is a great advantage. 'Why, what did you do there?' --- they don't like that very much (interview, Liga official, Delhi Packard) 
We don't speak about wages.... What is more important are techniques of bargaining, because when you go in and say the company's profits are such and such, they just say get lost and don't even speak to us; but when we prepare the negotiations well, for example with rates of inflation etc., that is very helpful (interview, MSzOSz official, Falco)

It has proved extremely difficult to establish workplace representation in Hungary with the help of cross-border networks. One interviewee mentioned cases where Austrian and Hungarian unions offered information and advice at workplace assemblies on how to set up works council representation, yet local workers did not take any action. While ÖGB and IRTUC practices are considered good templates, the very different context in Hungary often renders them inadequate. This is highlighted, for example, through the way information events were organized outside the workplace:

In those companies where we do not have access, legally, our only option is to organize socalled open-day information events [but only] 3 percent of these infodays were successful.... Very few have realised this, that it would be good to organize a union, very few, only 3 percent. Still, until the workers themselves realise that this is beneficial, this won't change. We have many good ideas, have brought out publications and brochures, but that does not get across. (interview, MSzOSz official, Vas)

In other cases, union or works council representation exists in Hungarian subsidiaries but the employer refuses to negotiate a collective agreement (for example at Eybl International, which makes textile products for the automotive industry). In such cases, the Austrian industry union can try to put pressure on the home-country management (interview, MSzOSz official, Vas). Lack of capacity at the workplace, however, leads local officers to rule-of-thumb bargaining rather than informed wage claims. Also, competitive unionism in Hungary can make cross-border cooperation more difficult. Efforts to establish cooperation in Delphi Packard, for example, had to overcome initial reservations between the main regional player (MSzOSz) and the dominant union at company level (Liga) (interview, MSzOSz official, Vas).

The weakness of Hungarian labour results in a circle of 'strategic displacement': while thin workplace presence makes county and regional unions focus on corporatist involvement and the (hard to achieve) sectoral social dialogue, efficient implementation of the latter requires workplace presence. Thus, industry level fora and cooperation activities under IRTUC auspices substitute for weak indigenous structures. 


\section{The IRTUC as social partner}

Another function that is central to IRTUC activities is its role as a social partner. Where labour market control and unionization are relatively high, as is the case in Burgenland, the social partner function at regional level ensures a link between workplace presence and labour market policies; where the former are weak as in Western Hungary, social partner involvement in labour market policies substitutes for collective power.

A number of interregional networks between social partners have been built around policymaking and implementation, particularly regarding the specific category of cross-border commuters. Regular contacts have been developed not only with the regional trade union confederations and chambers of labour but also with the public employment service, the health, occupational injury and pension insurance boards, the Austrian inspectorates for foreign employment and forestry, the Hungarian County Labour Councils and development councils, as well as a number of training institutions on both sides of the border. This has allowed the IRTUC to develop considerable technical expertise in social and labour market monitoring and to acquire an important voice in a number of institutions dealing with the interregional labour market. The most important institution in this respect is the international joint commission on cross-border commuters which decides on quotas for the latter as well as job placements.

We can say that we are in almost daily contact with our partners, and there are certain issues where the labour market organizations are forced to consult each other. There are regional agreements on cross-border commuters, students on job placements etc. All counties, as well as the regional public employment office, have tried to build their own contacts. (interview, MSzOSz official, Győr-Moson-Sopron)

Further, the IRTUC is consulted through the ÖGB Burgenland by the public employment office on the allocation of work permits or the development of a 'blacklist' of agricultural establishments that have not complied with labour law, resulting in fewer or no work permits for those enterprises (ÖGB/IGR, n.d.). One interviewee held that 'the experience and expertise of the IRTUC is reflected in the decisions of the advisory board of the public employment office' (interview, IRTUC official). This monitoring of labour market trends and quotas was also important as the basis for the decision (in fact the ÖGB's veto) not to open the labour market in 2007; instead, a flexible quota system for skilled workers was introduced in 2007 and expanded in 2008 (from 3 to 50 occupations or professions not subject to a quota).

The Euroregion provides an additional framework for trade unions' engagement as social partners, particularly as it overlaps exactly with the IRTUC labour market. However, despite parallel structures in the Euroregion and the IRTUC, the unions' representation in the former is through their 
national channels. Thus, instead of being directly involved in social affairs, business, development and training, as was initially hoped (interview, MSzOSz official, Vas), the IRTUC is not represented as such in the Euroregion. The same goes for an interregional employment pact that was concluded in June 2007 between the Austrian and Hungarian regional governments. Again, the regional unions are involved through the social partner arrangements in their respective countries, although employeerelated activities of the pact can be integrated with existing IRTUC activities (Verein Dialog, 2007; interviews, MSzOSz officials, Vas and Győr-Moson-Sopron).

Having built up an extensive system of information and interest representation, the IRTUC has become an important interregional network broker between trade unions and government institutions, and has gradually expanded its role from core labour market issues to social policy and training (Gutknecht-Gmeiner and Henkel, 2005; ÖGB/IGR, n.d.). Although this social partner role functions through different corporatist dynamics at national level, involvement in the policy community of the Euroregion has certainly been a factor in advancing important elements of the interregional labour market (legal representation, benefits and tax regulations for cross-border workers, employment service in the regions as well as in the context of EURES-T, vocational education and training, allocation of labour market funds) (interview, MSzOSz official, Falco). Furthermore, the social partner function has raised the political profile of the regional trade unions, that is the traditional social partnership role of the ÖGB Burgenland as well as the very weak regional structures of MSzOSz. Finally, it places regional trade unions into the multi-level system of European politics, that is into EU cohesion policies as well as within ETUC structures. However, given the structural incongruence between the two industrial relations systems (sectoral collective bargaining vs. patchy company-level bargaining), cross-border trade union cooperation remains focused on bottom-up initiatives to increase labour market control, through networking, coordination and capacity building.

\section{Trade union cooperation under asymmetry}

The function of trade union cooperation at the (sub-national) interregional level is to protect minimum wages and social standards in cross-border regions marked by considerable disparities. In the absence of product market control or a role in wage bargaining, it is the social function of trade union cooperation --- the preservation of minimum wage levels, benefits and labour rights, particularly in sectors with strong precarious employment --- that is crucial in cross-border regions. This is even more pronounced where economic and social disparities come with considerable differences in the strength of industrial relations systems and trade union capacity: here, bottom-up strategies of labour market control are much more central than they would be between regions with high collective bargaining coverage. Yet, in the context of competitive regionalism, cooperation on cross-border labour market issues does not necessarily result in a balanced approach to reduce economic and social differentials. 
While 'East-West-IRTUCs', in particular suffer from pronounced asymmetries, each case needs to be analysed separately as to what strategies of labour market control and capacity building are employed, the way in which different industrial relations institutions, interests and resources are shaped into new forms of cooperation that engage workers and establish more permanent forms of representation. The strategic orientation, trade union capacity and (in most cases) the bridging of the East-West gap are central themes in this respect.

First, the institutionalization and differentiation of IRTUC strategies ranges from a network node, a resource for campaigning and building trade union capacity, a platform to organize crossborder company- and sector-level networks, to an interregional social partner function (ETUC, 2009; Müller, 1994; Noack, 2001). The strategic compromise on these orientations is influenced by the role of regional labour movements and the kind of interregional cooperation that is possible across contrasting systems of industrial relations and labour market regulation. At interregional level, this compromise can be located in the triangle of state, market and society developed by Hyman (2001).

Second, with regard to capacity, the challenge lies in developing forms of cooperation that go beyond unilateral defensive measures on one side of the border and aim to build labour capacity throughout the cross-border region. For example, weak trade union capacity in Hungary has crucial implications for strategies of cross-border cooperation, which becomes most evident in the following dilemma. Neumann has argued that 'many company agreements are far from being real negotiated agreements, but are either defined unilaterally by employers or, following state socialist traditions, simply repeat the law' (2002:12). Weak workplace organization is further complicated by inter-union competition as well as a duplication of employee representation between works councils and unions (Tóth, 2000). On the other hand, multi-employer sectoral bargaining has also failed to develop into sustainable practices. Even though Hungarian trade unionists aim to emulate the corporatist Austrian approach, any replication in a different societal context is bound to be extremely problematic. Thus, different institutions and strategic capacities largely delimit the constraints (as well as the challenges) of cross-border trade union cooperation in general: while it takes workplace organization in order to strengthen sectoral and regional unions, it takes strong unions at the sectoral and regional levels in order to organize workplaces.

Finally, economic disparities and differences in organizational capacity influence the quality of cross-border cooperation that is possible. Unless the asymmetry in trade union capacity is addressed, cross-border cooperation will find its limits in protecting minimum wages and terms of employment for workers on the Austrian side, thereby protecting the asymmetry rather becoming an actor in shaping labour market convergence. Lévesque and Murray (2007) argue that a combination of top-down and bottom-up approaches is best suited to articulate contending needs across different levels and borders. In this respect, the IRTUC West Pannonia has developed the Stammtisch format to create important informational and social network capacity, for union representatives as well as workers. At the sectoral and company levels, cooperation is contingent on the existence of union 
organization on the Hungarian side. The social partner role is where the IRTUC has been most beneficial for Hungarian unions, as it clearly raises their political profile in tripartite regional labour market institutions. Through such initiatives the IRTUC has helped to build organizational capacity --articulate different union levels across the border and train/socialize a new generation of trade unionists --- in a very difficult phase of transition. The bottom-up focus on labour market control in these forms of cross-border cooperation can assist trade union revival in Eastern Europe (Ost, 2009); it might also gain in importance in the context of the decentralization of bargaining (Traxler et al., 2008: 234) and competitive regional development. However, the quality of cooperation is crucial here, as is the articulation of workplace, industry and national strategies.

\section{Acknowledgements}

I am grateful to the IRTUC, ÖGB, MSzOSz and Liga representatives for granting me time, Eszter Tóth and Eva Müller for facilitating contacts, Attila Kelemen for translation. I also appreciate productive feedback by the editor and two anonymous referees, as well as seminar participants at the IRRU, University of Warwick; CLMS at the University of Leicester provided start-up funding.

\section{References}

Commons, J. R. (1909) ‘American Shoemakers, 1648-1895: A Sketch of Industrial Evolution’, Quarterly Journal of Economics (24)1, 39-84.

Donaghey, J. and Teague, P. (2006) 'The Free Movement of Workers and Social Europe: Maintaining the European Ideal', Industrial Relations Journal (37)6, 652-66.

Dörre, K. and Röttger, B., eds (2005) Die erschöpfte Region. Politik und Gewerkschaften in Regionalisierungsprozessen. Münster: Westfälisches Dampfboot.

ETUC (2009) Interregional Trade Union Councils (IRTUCs) - Collective Bargaining - Cross-border Cooperation. Brussels: ETUC.

Gollbach, J. and T. Schulten (2000) 'Cross-Border Collective Bargaining Networks in Europe', European Journal of Industrial Relations (6)2, 161-79.

Grundtner, H. and Eberl, G. (2006) Handbuch für Berufskraftfahrer/Hivatásos gépkocsivezetök kezikönyve. Vienna: LexisNexis ARD Orac.

Gutknecht-Gmeiner, M. and Henkel, S. (2005) Interregionaler Gewerkschaftsrat (IGR) Burgenland West-Ungarn der ÖGB LEX Burgenland im Rahmen von INTERREG III: Zwischenevaluierung. Vienna: ÖIBF.

Hamann, P. (2005) 'Défendre les travailleurs frontaliers: Les apprentissages de la légitimation dans l’Union Européenne', Revue Française de Science Politique (55)3, 445-76 
Horesnyi, J. and Tóth, F. (2006) 'Regional Industrial Relations', in K. Fazekas and J. Koltay (eds) The Hungarian Labour Market. Review and Analysis 2006, pp. 75-91. Budapest: Institute of Economics, HAS \& Hungarian Employment Foundation.

Hyman, R. (2001) Understanding European Trade Unionism: Between Market, Class and Society. London: Sage.

IGR (n.d.) Informationen zum IGR (unpublished manuscript)

IGR Burgenland/Westungarn (1999) Interregionaler Gewerkschaftsrat Europa-Region BurgenlandWestungarn. Eisenstadt: IGR.

Lecher, W., Platzer, H., Rüb, S. and Weiner, K. (2001) European Works Councils: Developments, Types and Networking. Aldershot: Ashgate.

Lévesque, C. and G. Murray (2007) Local Union Strategies in Cross-border Alliances: Building Proactive Solidarity, paper to IIRA European Regional Conference, September.

Marginson, P. (2005) 'Industrial Relations at European Sector Level: The Weak Link?', Economic and Industrial Democracy (26)4, 511-40.

Marginson, P. and Traxler, F. (2005) 'After Enlargement: Preconditions and Prospects for Bargaining Coordination', Transfer (11)3, 423-38.

Marginson, P. and Sisson, K. (2004) European Integration and Industrial Relations: Multi-level Governance in the Making. Houndmills: Palgrave.

Müller, G. (1994) ,Grenzerfahrungen. Arbeitsfelder Arbeitsweisen und Arbeitshemmnisse Interregionaler Gewerkschaftsräte', WSI Mitteilungen (47)4, 257-64.

Neumann, L. (2002) 'Does Decentralised Collective Bargaining Have an Impact on the Labour Market in Hungary?', European Journal of Industrial Relations 8(1): 11-31.

Noack, J. (2001) 'Interregional Trade Union Councils in the Run-up to Eastern Enlargement of the EU', in E. Gabaglio and R. Hoffmann (eds) European Trade Union Yearbook 2000, pp. 337-354. Brussels: ETUI.

ÖGB/IGR (2007) IGR-Symposium 'Zukunft-Grenzraum-Arbeitsmarkt'/IFES Studie 'Entwicklung des Arbeitsmarktes im Grenzraum Burgenland/Ungarn während der Übergangsperiode'. Eisenstadt: ÖGB.

ÖGB/IGR (n.d.) Interreg IIIA Projekt 'Interregionaler Gewerkschaftsrat (IGR) BurgenlandWestungarn'. Eisenstadt: ÖGB.

Ost, D. (2009) 'The Consequences of Postcommunism: Trade Unions in Eastern Europe's Future', East European Politics and Societies (23)1, 13-33.

Perkmann, M. (2007) 'Construction of New Territorial Scales: A Framework and Case Study of the EUREGIO Cross-Border Region’, Regional Studies 41(2): 253-66.

Polsterer, A. (2002) 'Analyse der grenzüberschreitenden Arbeitsmarktbeziehungen zwischen Burgenland und Westungarn', in A. Polsterer (ed.) Grenzüberschreitenden 
Arbeitsmarktbeziehungen zwischen Burgenland und Westungarn, pp. 1-35. Eisenstadt:

Burgenländische Forschungsgesellschaft.

Schulten, T. (2003) 'Europeanisation of Collective Bargaining: Trade Union Initiatives for the Transnational Coordination of Collective Bargaining', in B. Keller and H. Platzer (eds) Industrial Relations and European Integration, pp. 112-36. Aldershot: Ashgate.

Tóth, A. (2000) 'Attempts to Reform a Workers' Movement without Mass Participation', Waddington, J. and R. Hoffman (eds) Trade Unions in Europe, pp. 305-38. Brussels: ETUI.

Traxler, F., Brandl, B., Glassner, V. and Ludvig, A. (2008) 'Can Cross-Border Bargaining

Coordination Work? Analytical Reflections and Evidence from the Metal Industry in Germany and Austria', European Journal of Industrial Relations (14)2, 217-37.

Traxler, F. and E. Mermet (2003) Coordination of Collective Bargaining: The Case of Europe, Transfer (9) 2, 229-246

Verein Dialog (2007) Grenzüberschreitende Beschäftigngsvereinbarungen in der Euregio West/Nyugat Pannonia. Unpublished ms.

Visser, J. (2004) ,Patterns and Variations in European Industrial Relations', in European Commission, Industrial Relations in Europe 2004, pp. 11-58. Luxembourg: OOPEC.

\section{Author Biography}

Nikolaus Hammer is Lecturer in Employment Studies at the Centre for Labour Market Studies, University of Leicester. 